\title{
To what extent are pollutant emission intensified by international tourist arrivals? Starling evidence from G7 Countries
}

\author{
Bright Akwasi Gyamfi ${ }^{1}$ Murad A. Bein ${ }^{1} \cdot$ Festus Fatai Adedoyin ${ }^{2}$ (D) \\ Festus Victor Bekun ${ }^{3,4}$
}

Received: 18 May 2020 / Accepted: 16 August 2021 / Published online: 9 September 2021

(C) The Author(s) 2021

\begin{abstract}
A large volume of environmental science and pollution research has focused on the contributions of various forms of energy consumption to emissions. However, little attention is given to the impact of human activities such as tourism. Hence, this study investigates the impact of tourist arrivals, energy use, and economic growth on $\mathrm{CO}_{2}$ emissions in the G7 countries for the period 1995-2018. The study employed the use of dynamic panel estimations, namely dynamic ordinary least square, fully modified ordinary least squares and panel pooled mean group-autoregressive distributed lag model (PMG-ARDL) estimation techniques to establish long-run and short-run relationships between the study variable of interest, while the Dumitrescu Hurlin non-causality test was used to test for causality direction among the variables outlined. Empirical findings from the regression revealed that economic growth, tourism and energy use are strong drivers of emission levels in the G7 bloc, while the causality analysis revealed that there is unidirectional causality from $\mathrm{CO}_{2}$ to energy use, $\mathrm{CO}_{2}$ to economic growth (GDP) and GDP to tourist arrivals. These outcomes imply that tourism, energy use and economic growth have no direct effect on emissions, but rather emissions predict economic growth and energy use. Furthermore, tourist arrivals predict energy use; economic growth predicts tourism. Overall based on the study of empirical outcomes, we suggest that to achieve more significant results in reducing emissions, governments of the G7 countries should continue to emphasize green tourism as well as increase the share of renewable energy in their regional energy mix. More policy direction was outlined in the concluding section of this study.
\end{abstract}

Keywords Environmental pollution - Tourist arrivals · Energy use · Economic growth · $\mathrm{CO}_{2}$ emissions $\cdot \mathrm{G} 7$ economics

Festus Fatai Adedoyin

fadedoyin@bournemouth.ac.uk

Extended author information available on the last page of the article 


\section{Introduction}

The Group of Seven (G-7) is an intergovernmental association comprising of Canada, France, Germany, Italy, Japan, the UK and the USA. The heads of the legislature of the part state, and the delegates of the European Union, usually meet at the yearly G7 Summit to talk about global problems such as economic crisis, fiscal system and other burning issues. Starting in 2018, the G7 addresses 58\% of the worldwide net abundance ( $\$ 317$ trillion) over $46 \%$ of the worldwide total national output (GDP) because of ostensible qualities and over $32 \%$ of the worldwide GDP dependent on purchasing power parity (IMF, 2017). The early function of the group of G7 is to increase the economics of its member countries as well as the global economy (Bayne, 1998).

According to the World Economic Forum (2016), the G7 was ranked as the highest developed economy with higher economic growth (GDP) rating and the world's most prominent export nations. Also, in the Global Competitiveness Index, the USA is ranked third behind Switzerland and Singapore. This is because of her potential for growth, greater business share and solid monetary structure. Germany has ranked in the fourth position thanks to her employment rate and fiscal well-being. Japan has also won the sixth position in its research and development operations. As for the UK, the rank was the tenth position, because the nation's key strength lies in privately managed alliances, an active legal mechanism, knowledgeable and professional labor and technical innovation. Canada rates 13th and handles higher expenditure on proper education and wellness. France is in 22nd position, thanks to its sustainable economic growth, reliable services, higher learning investment and a stable revenue base framework. Italy has won the 43rd position due to government changes and community development, supported by flexible fiscal policy and rising internal competition, which stimulates investment by businesses to boost competitiveness (World Economic Forum, 2016).

However, no nation will progress without an adequate vibrant economic structure contributing to such a nation's economy. This required sustainable development growth from different sectors of the economy such as the health sector, energy sector, international travel and tourism, which is the main variable in this study. Travel and tourism are inseparable because mobility in one produces a surmountable effect in another (Trend, 2014). That is, tourist activities required international travel, either by road, water or aviation, for the tourist to transit across the globe. So, in this study, the two are used interchangeably to refer to the same meaning. Considering the relationship between travel and tourism, $\$ 896.9$ billion of the $\$ 2.7$ trillion of the GDP of the airline industry was accounted for by activities that induced tourism. This means that only the airline industry contributes $3.6 \%$ of the global GDP (ATAG, 2019). In addition, according to Wikiversity (2016), the second largest industry in the world is travel and tourism. Bearing this in mind, the economic growth of a large number of countries and nations was significantly contributed by the travel and tourism industry. Considering the rapid increase in international tourism demand over the last few decades, it can be conjectured that international travel is the major reason behind economic growth, having about 10 and $7 \%$ of the world economy and exports, respectively (UNWTO, 2016). In support of UNWTO statistics, the Economic Influence Survey of the World Travel and Tourism Council (2016) also illustrated the overall commitment of transportation and hospitality, which amounts to around US\$ 7.2 trillion (estimated 9.8\%) of global GDP. It goes on to indicate that the sector has generated almost 1:11 employment on the planet which demonstrates the creativity of this industry to elevate the standard of living of people, who rely on the industry. 
Streamlining to G-7 countries, Fig. 1 reveals the number of international tourism arrivals in 2019 by the top 10 . Of these, five out of G7 countries made the list which France having the maximum number, attracting 89.4 million tourists, followed by the USA attracting 83.5 million tourist arrival after Spain which attracts 85 million international arrivals. The figures also denoted that France attracted. In this context, G7 countries are one of the most visited countries in the world. According to the Euromonitor International report (2014) and Brilliant Maps (2015), 4.7 million visitors have toured two major locations in Canada, Toronto as well as Vancouver, whereas Paris in France welcomed about 12 million visitors in 2015. Further, the main locations in Italy, such as Rome, Florence and Venice, got 13.7 million visitors visiting such locations. Tokyo in Japan (3.7 million visitors), London in the UK (15.5 million visitors) and numerous locations in the USA, such as New York City, Las Vegas, Miami, Los Angeles, Orlando, San Francisco, Honolulu and Washington D.C., also attracted 39.9 million tourists in 2015.

This is expected that perhaps the G-20 members would surpass before 2026, as China, Germany, the USA and the UK would continue at a faster pace which will be the largest, four industry leaders, by 2026 over international air investment.

The numerous visits and attractions caught the eye of policymakers to maintain and develop tourism facilities for wide-based development in the field. These facts support the importance of travel and tourism in improving the economic sector. Accordingly, Stynes (1998) posited that the overall impact of tourism represents the revenues and earnings of businesses, who are actively involved in tourism operations. Except for overnight visits, international visitors trip in accommodation and eventually boost the hotel revenues and profits, thereby easing the cumulative tax burden of the hotel, thus providing advancement to the progress of the country. Another influence of tourism is that an increase in tourism activities creates employment possibilities at a tourist destination, thus boosting the living standards of the population through means of financial exchange.

\section{9 global International tourist arrivals by top 10 countries (in millions)}

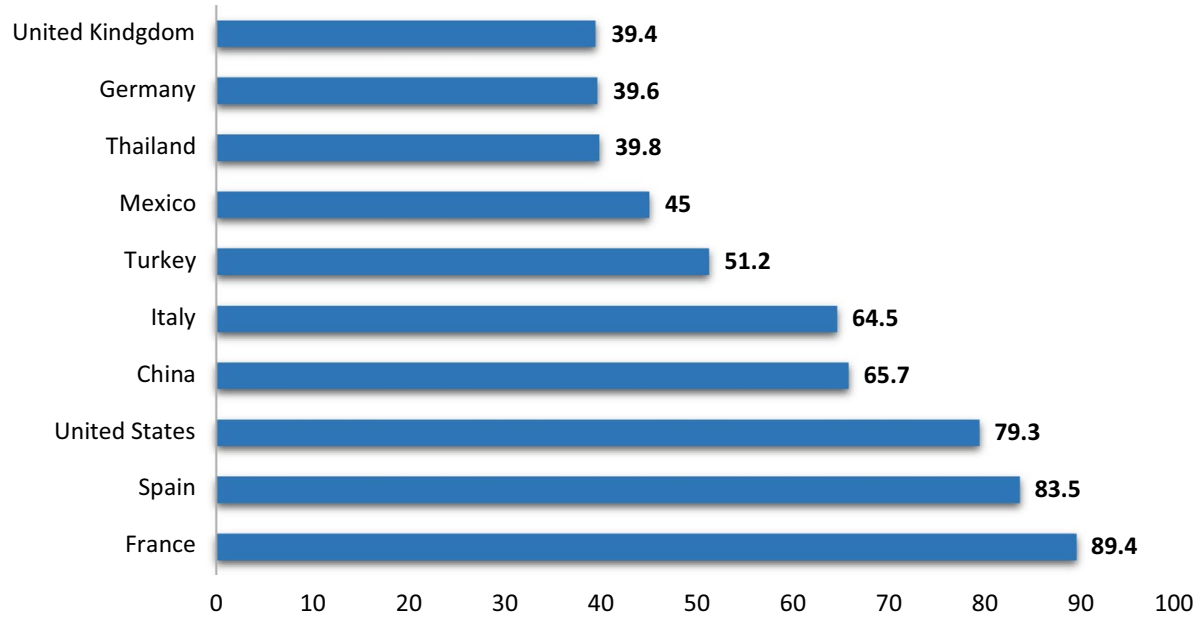

Fig. 1 Top 10 international tourism arrivals by country. Source: The United Nations World Tourism Organization (UNWTO) 
UNWTO forecasted that international tourists' arrival is expected to rise to 1.8 billion by 2030. However, although travel and tourism contribute to $7 \%$ of global exports and $10 \%$ of global GDP, it also produces $5 \%$ of world $\mathrm{CO}_{2}$ emissions, thereby causing environmental harm. As a result of the sheer volume of tourism products, negative impacts occur especially when the number of visitors is greater than the environment's ability to cope with the visitor volume. Mbaiwa (2003) claimed that even the deterioration of the industry in ecosystems contributes to the rise in environmental quality, which includes viable strategy solutions to rebuild tourism destinations. Gao and Zhang (2019) verified the foreign investment-induced EKC phenomenon throughout various Mediterranean communities using certain informal assumptions, i.e., the Northern Zone validated the feedback phenomenon regarding tourismled development or even energy usage, whereas the Southern Zone has a tourism-led development theory, showing clear strategy assumptions for developing tourism facilities in the corresponding states. Balli et al. (2019) have highlighted the involvement of the green leisure industry in reducing greenhouse gas pollution across nations. This restricted position of tourism is related to complex causal interlinkages that endorse whether the feedback assumption and/or the tourism-led development assumption in the country description. Saint Akadiri et al. (2019) used globalization throughout international tourism as well as energy usage modeling to verify the moderating role of globalization in the fulfillment of the EKC theory, which is crucial to the achievement of the nation's environmental sustainability targets. Liu et al. (2019) endorsed a green tourism policy that helps minimize greenhouse gas pollution, whereas the ongoing EG and energy requirement are expected to be the key corollaries that dramatically raise carbon pollution around the region. Sustainable green strategies are also crucial to rising adverse external costs that can be sponsored economically by the green tourism campaign. Shaheen et al. (2019) indicated such a necessity to develop international tourism facilities by increased energy sustainability or even electricity consumption, which will vastly increase international tourism sales, which are further redistributed in enhancing ecological standards and connectivity throughout nations.

Given the foregoing trajectory, this study aims to examine the effects of international tourist arrivals on pollutant emission in G7 countries. Given that travel and tourism consume energy to contribute to the gross domestic product, which measures the economic growth of a nation (Abdulnasser, 2019), this study also incorporates energy consumption and GDP effects on pollutant emission in G7 countries. Global warming is the primary concern of the G7 reform ideology, which provides innovative reform mechanisms to reduce greenhouse gas pollution. Habitat destruction, degradation and ecological violence are critical concerns that need to be tackled by green policy to support wide-based development. Hence, it is important to examine how pollution generated by these visitors affects the environment in the long run. Furthermore, the findings also provide a better image of the tourism business in the countries from an ecological point of view to influence the course of legislators and governing agencies.

The remaining chapters are structured as follows: Sect. 2 outlines the literature review; Sect. 3 addresses approaches and methods; Sect. 4 discusses the results and implication of research findings; finally, the conclusion is presented in Sect. 5 


\section{Review of literature}

\subsection{Theoretical framework}

While achieving sustainable economic growth, developing countries are on the verge of expanding sources of income generations for their states. This could be in the form of increasing nations wealth through maintaining higher growth domestic product, which, itself, cannot happen if there is no adequate source of income from various means such import and export industries, tourism industry which cater for international tourists' arrivals, foreign direct investment, etc. However, these means, especially international tourist arrival, which, according to the United Nation World Tourism Organization, contribute to almost $10 \%$ of the world GDP required large consumption of energy (renewable or non-renewable energy) to happen, and the release of toxic chemicals from the energy consumption harms our environment to an undesirable or abnormal extent.

As clearly outlined by the UNWTO there has been a global increase in the influx of international inbound and outbound tourism for recreation and its inherent benefit for national development. This trajectory of international tourism arrival is seen to increase energy demand, especially in tourism-dependent blocs. Thus, validating the twin growth hypotheses of both tourism and energy-led growth hypotheses (Cheam et al., 2013; Katircioglu, 2014). The theoretical motivation for this study stems from the tourisminduced environmental degradation preposition which is anchored the trade-off between economic expansion and environmental quality in terms of long-run and causality analysis in our study case for the G7 bloc (Adedoyin \& Bekun, 2020). The intuition is linked to the fact that both tourism inbound and outbound have been outlined as core drivers of global emission as tourism development attract more energy consumption especially non-renewable energy consumption and which induce emission level. This phenomenon aligns with the EKC concept that highlights the trade-off between GDP growth and environmental degradation. In our study case, the conventional EKC framework is augmented by both conventional energy from fossil fuel and international tourism arrival on emission level.

Furthermore, Gossling (2013) has reported that tourism leads to 5-15 percent of total greenhouse gas pollution. The reason is that tourism is a much more energy-intensive field that explicitly or implicitly consumes power, electric power, gas, coal, fuels and produces greenhouse gases, in particular carbon emission. Gossling and Peeters (2015) indicated the effects of the energy usage for a specific tourist ride generate pollution of $0.1-260 \mathrm{~kg}$ of $\mathrm{CO}_{2}$ emission. Moreover, $1.12 \mathrm{Gt}$ of $\mathrm{CO}_{2}$ emanation also remained released worldwide during 1900-2010. In this context, the reasons for abnormalities in environmental qualities are necessitated by environmental degradation caused by greenhouse gas discharge such as carbon dioxide, nitrogen oxide, water vapor. As a result, climate warming and greenhouse gas emissions have remained at the forefront of debate throughout the research on ecological and energy economics. So far, several researchers have sought to figure out the predictors of $\mathrm{CO}_{2}$ production which have been tested throughout various circumstances. Also, considering the gross domestic product and energy consumption, scholars have inferred contradictory conclusions by using separate factors and processes, resulting in inconsistent findings (Adedoyin et al., 2020a, 2020b; Kirikkaleli et al., 2020; Udi et al., 2020), while each portion of the report was meant to address key issues that made a significant contribution to policy direction. 


\subsection{Tourism and pollution nexus}

Global tourism involved traveling to areas of outdoor appeal and excitement, where the atmosphere is good, and the brain is refreshed. It is vital for the outstanding growth of several countries across the continents for green sustainability (Azam, \& Abdullah, 2021; Balsalobre-Lorente et al., 2020, Hunter \& Green, 1995; Hughes, 1996); Lukashina et al., 1996; Pigram, 1980. Currently, tourism on the planet requires various transport services, namely air travel, motor vehicles and vacation vessels, and many more, which need vigor supplies to function. The partnership regarding the intercontinental vacation industry and green sustainability cannot however be deemed to be ecofriendly. To endorse this claim, Gossling (2002) claimed that 94 percent of the exposure to worldwide change is attributed to the transport industry. Gossling and Hall (2006) investigated the correlation regarding inbound tourism in addition to the air contamination and found that much of the air contamination is caused by the travel business. Peeters et al. (2007) examined that inflight travel and foreign tourism industry are the major sources of airborne contamination. In the same vein, Byrnes and Warnken (2006), Howitt et al. (2010); Lin (2010), Scott et al. (2010) researched the interaction between tourism and ecological pollution. Their results found that the pollution is caused transportation and airline industry.

Adhering to UNWTO (2008) report, 75 percent of the $\mathrm{CO}_{2}$ pollution from the tourism industry are generated by transport (in general 40 percent by in-flight travel, 30 percent by vehicle and 3 percent by other travel), thereby 21 percent than 4 percent by lodging and visitor operations, however. Howitt et al. (2010) noticed that transportation by cargo vessels is more harmful to pollutants than mid-flight travel. Many scholars have established econometric estimates of the effect of tourism-based variables on $\mathrm{CO}_{2}$ emissions. Katircioglu (2014) illustrated Turkey in place of tourism destination enjoyed 30 million visitors per year. Katircioglu listed electricity usage as an external aspect for the vacation industry which causes also $\mathrm{CO}_{2}$ emissions. The result shows that a $1 \%$ increase in visitor presence generates 0.10 percent of $\mathrm{CO}_{2}$ pollution in the extended term. Related research in Cyprus finds that a 1 percent rise in tourist presence contributes to 0.03 percent $\mathrm{CO}_{2}$ emissions (Katircioglu, 2014). Scott et al. (2010) researched the potentially extraordinary production of $\mathrm{CO}_{2}$ with tourism. They estimated that the tourism sector may be the world's largest producer of greenhouse gases in the atmosphere in the foreseeable future, thus concluding that major policy effects and realistic improvements in air transport would be a way to correct the situation. Aissa et al. (2014) deemed the connection regarding greenhouse gas pollution, economic development, green energies and the influx of visitors. Utilizing panel data for the span 1995-2010, the quantitative findings have shown that clean energies and visitor entrants harm $\mathrm{CO}_{2}$ pollution. They suggested that the influx of visitors would lead to a long-term decrease in carbon. In addition, Solarin (2014) discussed the long-term relationship involving $\mathrm{CO}_{2}$ pollution and tourist arrivals, alongside many supplementary macroeconomic variables in Malaysia. Durbarry and Seetanah (2014) used the panel data from Mauritius from 1978 to 2011 and noticed that there was a good association between both the release of $\mathrm{CO}_{2}$ and the arrival of tourists.

Furthermore, Lee and Brahmasrene (2013) also inspected 27 members of the European Union. The results revealed that the factors in the issue were co-integrated. However, the study found that there is a long-term balance negative association between tourism and $\mathrm{CO}_{2}$ pollution. The study showed that the factors under consideration had 
a favorable effect on economic development. By following a bottom-up strategy, Tang and Abosedra (2014) found that the $\mathrm{CO}_{2}$ pollution from the tourism sector was nearly eight times greater in 2012 than that in 1990 in China. The tourism industry's production of $\mathrm{CO}_{2}$ is considerably greater than the cost of travel-related travel $(80 \%$ of overall pollution). Al-Mulali et al. (2015) studied the association between the influx of visitors and the production of $\mathrm{CO}_{2}$ in the transport industry. Test testing was carried out in five separate areas (Africa; Middle East; the Americas; Asia and the Pacific; and Europe). Illustrative factors, in the form of the influx of visitors, electricity use and urban growth, have had a positive effect on $\mathrm{CO}_{2}$ pollution, given the fact that the market for the vacation industry in the European section is relatively weak. Stefanica and Butnaru (2015) claimed that the vacation industry is dependent on stylish of beautiful, pleasant in addition to the sustainable atmosphere than that ecological degradation, in the form of greenhouse gases and excess emissions, could interrupt and threaten the attractiveness of the world. Such influences can affect the buying behavior of consumers. Regarded the interaction involving $\mathrm{CO}_{2}$ pollution, productivity growth, green energy and the influx of visitors. Utilizing panel statistics for the span of 1995-2010, the empirical findings revealed that clean energies and visitor arrivals harmed $\mathrm{CO}_{2}$ emissions. They suggested that the influx of visitors would lead to a long-term decline in emissions. Additionally, Azam et al(2018) study also resonated the tourism-induced emission level in Malaysia, Singapore and Thailand. The study reports that tourism shows a significant positive effect on the environment in Malaysia, while negative for Thailand and Singapore.

\subsection{Energy use and pollution}

The connection involving energy use and $\mathrm{CO}_{2}$ pollution has been the key point of contention in the energy and ecological establishment for decades. This section is split into dual parts. The first segment refers to the link between the growth of the economy and energy usage, and the next segment refers to the association between energy usage and $\mathrm{CO}_{2}$ pollution. Most of the research has suggested strong ties regarding them. Efficient practices of any community are made up of the farming, processing and utility parts of the community, which require the use of vigor supplies to comply using the global fiscal growth. Such vigor supplies recycled throughout the system of change are primarily non-renewable effects, which release a lot of GHGs into the ecosystem, thereby compromising the sustainability of the ecosystem and natural mankind. Zhang and Cheng (2009) have observed that GDP induces energy utilization in addition to long-term environmental emissions incurred by vigor utilization. In a survey of eight Asia-Pacific countries, Meng and Niu (2011) reported a long-term agreement, respectively, on $\mathrm{CO}_{2}$ production, vigor utilize and fiscal advancement. Analogously, in the analysis of 27 industrialized nations, Saboori and Sulaiman (2013) showed a bi-directional correlation between energy utilization in the road traffic market, transport $\mathrm{CO}_{2}$ exposure and economic advancement. The result revealed a clear positive association involving $\mathrm{CO}_{2}$ pollution and energy utilization for both the long and short term, incorporating the ARDL as well as Granger causality method in the VECM panel evidence from Southeast Asian communities.

In addition, trend analysis results from the UAE headed by Sbia et al. (2014) showed that there was a strong correlation between energy consumption and economic growth. Akpan and Akpan (2012) also show that urbanization is unique to the basic drivers of the rise in $\mathrm{CO}_{2}$ concentrations increasing electricity utilization. In conjunction, Ali et al., 
(2017a, 2017b) reviewed the EKC (environmental Kuznets curve) hypothesis for the Malaysia study, and the result suggested that energy use and GDP growth are primary drivers of $\mathrm{CO}_{2}$ production in the country. The survey also demonstrates that there was a bidirectional causal correlation involving $\mathrm{CO}_{2}$ concentrations and energy utilization, whereas economic advancement and other unidirectional indicators were affected by Granger $\mathrm{CO}_{2}$ emitted. Additionally, Pao and Tsai (2010) find that long-term $\mathrm{CO}_{2}$ concentrations are inelastic to production, whereas energy utilization tends to be elastic. The observations also indicate the involvement of bi-directional cause and effect.

In another perspective, Lotfalipour et al. (2010) reported, in the scenario of Iran, whereby long-term $\mathrm{CO}_{2}$ production and utilization of fossil fuels do not harm one another. More recently, Azam et al (2018) explored the nexus between energy consumption, economic growth and environmental quality for China. The country is reputed as among the high emitter of CO2 globally. The study employed the use of canonical cointegrating regression technique to investigate the relationship between foreign direct investment, energy use environment and economic growth. Empirical restudy shows that energy use has a significant positive effect on energy consumption, FDI environment and economic growth. These outcomes led to suggestions for a more effective policy for effective utilization of energy utilization in China that can be pursued by government officials and stakeholders. Azam et al(2019) also alluded to the pertinent contribution of energy consumption to the top 10 Asian economies as outlined by pooled mean group, fully modified ordinary least squares and dynamic ordinary least squares that gave credence to the energy-induced growth hypothesis in the investigated bloc. However, causation is to be taken on its environmental implications.

\subsection{Economic growth and pollution nexus}

The connection involving economic activity and the ecosystem is a subject of discourse among several researchers in the current century. Adhering to Beckerman, there will be a major connection regarding profits and environmental conservation initiatives to reduce carbon pollution in the long run. For the very first time, Grossman and Krueger (1991) subsequently explored that urbanization would regulate the state's $\mathrm{CO}_{2}$ emissions without government intervention. Grossman and Krueger (1991) as well as Selden and Song (1994) proposed that the EKC link existed between sustainable development and protecting the environment, while proposed that enhancing the efficiency of the ecosystem if productivity growth is limited, environmental deterioration can be declined. Schmalensee et al. (1998) analysis suggested a pivotal moment, which would be a better indicator of the twisted U-shaped relation around per capita revenue versus $\mathrm{CO}_{2}$ concentrations from 1950 to 1990. However, in the instance of Malaysia, Ali et al., (2017a, 2017b) studied the association regarding sustainable development, power utilization and $\mathrm{CO}_{2}$ exposure in the context of supplementary regulation variables and then determined that productivity progress and energy utilization are core measures of environmental contamination. The study also turned out that greater social development will mitigate environmental emissions because there would be more spending on healthcare and prevention mechanisms, thus validating the role of EKC in the context of Malaysia. For the other extreme, there is a line of discourse that argues that urbanization is among the key causes of environmental destruction both within the established and growing world economies (Coondoo \& Dinda, 2008). In a related context, De Bruyn et al. (1998) discussed that fiscal expansion is the major origin of 
ecological deterioration and that there was no confirmation of an ECC association involving GDP growth and $\mathrm{CO}_{2}$ leakage, other than a long-term $\mathrm{N}$-shaped association, as there would be more ecological waste after a certain amount of investment (Howitt et al., 2010).

Likewise, several studies were undertaken in Turkey (Jalil et al., 2013) found that a rise in economic activity contributes to a greater increase in quantities of $\mathrm{CO}_{2}$ contamination in the atmosphere, besides an N-shaped association occurs regarding fiscal activity and $\mathrm{CO}_{2}$ pollution slightly than an inverse U-shaped association. Furthermore, in the situation of Turkey, Johanses and Juselius (1990) observed that there was no proof of an EKC association involving $\mathrm{CO}_{2}$ pollution and economic development, although a linear association was formed between both variables. Not yet necessarily, in the scenario of Malaysia, Ali et al., (2017a, 2017b) introduced the new trigger model and showed no proof of the historical association involving GDP progress and $\mathrm{CO}_{2}$ pollution in the face of systemic improvements and energy utilization.

Although most previous studies attest that international tourist arrivals, energy consumption and economic growth contribute significantly to pollutant emissions, yet there is no consensus in empirical outcomes. First, few strands of literature believed that, in the context of EKC, economic growth suppresses environmental degradation. Our study advances the arguments by augmenting the conventional linear carbon-income model with tourist arrival as a key determinant of GHGs for the case of G7. Second, to the best of our knowledge, few studies such as (Ișik et al, 2020; Wu et al., 2020) discuss the effects of international tourism arrivals using G-7 as a case study. However, this study employs robust econometric analysis consistent with literature such as pool mean group-autoregressive distributed lag (PMG-ARDL), dynamic ordinal least square (DOLS) and full modified ordinary least square (FMOLS) for long-run regression among the outlined study variables, while for detection of causality direction Dumitrescu and Hurlin causality test is employed. Our study relies on first-generation panel analysis. Furthermore, cross-sectional dependency (CD) test is used to accommodate the common shock effect among the blocs investigated for the robustness purpose as well as avoid spurious analysis. This study, therefore, filled the missing gaps by estimating the impact of tourism proxied by international tourist arrivals GDP which measures the economic growth and consumption of energy on emissions in G7 economies.

\section{Data and methods}

\subsection{Data and variables}

The yearly frequency data used in this study cover the period from 1995 to 2018 for G7 countries (i.e., USA, UK, Germany, France, Canada, Italy and Japan). The variables considered include tourist arrivals (number of tourists), GDP (measured in constant 2010 US\$), energy use ( $\mathrm{kg}$ of oil equivalent per capita) and $\mathrm{CO}_{2}$ emissions per capita (measured in metric tons). As shown in Table 1, all data are sourced from the World Bank Development Indicator (World Bank, 2020). For the $\mathrm{CO}_{2}$ emission, data from 1995 to 2016 were obtained from the World Bank Development Indicator (World Bank, 2020), while the remaining years (i.e., 2017 and 2018) data from the British petroleum database (Table 2) (BP, 2020). 
Table 1 Description of data and measurement units

\begin{tabular}{llll}
\hline Name of indicator & Abbreviation & Proxy/scale of measurement & Source \\
\hline Carbon dioxide emissions per capita & $\mathrm{CO}_{2}$ & measured in metric tonnes & WDI and BP \\
Gross Domestic Product & GDP & Constant 2010 US\$ & WDI \\
Tourist Arrivals & TR & Number of arrivals & WDI \\
Energy Use & EU & kg of oil equivalent per capita & WDI \\
\hline
\end{tabular}

WDI is a connotation for data from World Bank Development Indicator of the World Bank database sourced from https://data.worldbank.org/. WUI=This tab contains the beta version of the historical World Uncertainty Index (WUI) for 82 countries from 1952Q1 to 2019Q3. The tab contains a moving average index. The 3-quarter weighted moving average is computed as follows: 1996Q4 $=(1996 \mathrm{Q} 4 * 0.6)+(1996 \mathrm{Q} 3$ $* 0.3)+(1996 \mathrm{Q} 2 * 0.1) / 3$

Table 2 Correlation matrix Source: Authors computation

\begin{tabular}{lllll}
\hline Variables & $\mathrm{LnCO}_{2}$ & LnEU & LnGDP & LnTR \\
\hline $\mathrm{LnCO}_{2}$ & 1.000000 & & & \\
$p$ value & - & & & \\
LnEU & $0.533406^{* * *}$ & 1.000000 & & \\
$p$ value & $(0.0000)$ & - & & \\
LnGDP & $0.549936^{* * *}$ & $0.531230^{* * *}$ & 1.000000 & \\
$p$ value & $(0.0000)$ & $(0.0000)$ & - & \\
LnTR & $0.444069^{* * *}$ & 0.108392 & $0.270806^{* * *}$ & 1.000000 \\
$p$ value & $(0.0000)$ & $(0.1619)$ & $(0.0004)$ & - \\
\hline
\end{tabular}

\subsection{Model and method}

Several studies in the literature have investigated the nexus between tourism and $\mathrm{CO}_{2}$ emissions (Byrnes and Warnken, 2006; Gossling, 2002; Gossling \& Hall, 2006; Howitt et al., 2010; Lin, 2010; Scott et al., 2010; Peeters et al., 2007), while some others focused on energy and $\mathrm{CO}_{2}$ emissions (Akpan \& Akpan, 2012; Meng \& Niu, 2011; Saboori \& Sulaiman, 2013; Sbia et al., 2014; Zhang \& Cheng, 2009), yet some on GDP and $\mathrm{CO}_{2}$ emissions (De Bruyn et al. (1998); Coondoo \& Dinda, 2008; Howitt et al., 2010; Jalil et al., 2013; Ali et al., 2017a, 2017b).

However, this study is distinguished from previous studies in that it combines tourism, economic growth and energy use as determinants of $\mathrm{CO}_{2}$ emissions in the $\mathrm{G} 7$ countries which contribute more than $46 \%$ of global GDP. The model equations for this study are as follows:

$$
\begin{gathered}
\mathrm{CO}_{2}=f(\mathrm{GDP}, \mathrm{TR}, \mathrm{EU}) \\
\mathrm{LnC0}_{2}=\alpha_{0}+\beta_{1} \mathrm{LnGDP}_{i t}+\beta_{2} \mathrm{LnTR}_{i t}+\beta_{3} \mathrm{LnEU}_{i t}+\varepsilon_{i t}
\end{gathered}
$$

The study adopts a logarithmic transformation of all variables to ensure that the variance remains constant across all the series, where $\mathrm{LnCO}_{2}$, LnGDP, LnTR, LnEU are logarithmic transformations of all variables, $\alpha$ and $\beta$ s represent the stochastic, intercept and partial slope coefficients, respectively, and the $\varepsilon_{i t}$ represents the error term of the equation. As stated early, GDP represents economic growth, TR denotes tourism arrival, 
EU denotes energy use, and $\mathrm{CO}_{2}$ used as a dependent variable for the estimation denotes carbon dioxide emissions per capita, slope coefficients, respectively.

To ascertain whether to apply the first-generation or the second-generation panel data econometric technique, the cross-sectional dependency (CD) test was carried out. The estimators are incomplete, contradictory and useless if the CD is not considered (Adedoyin et al, 2021). The study used the CD test for the robustness purpose. The CD test takes a null hypothesis of no cross-sectional dependence, and the equation is specified as:

$$
C D_{p}=\left(\frac{1}{N(N-1)}\right)^{\frac{1}{2}} \sum_{i=1}^{N-1} \sum_{j=i+1}^{N} T_{i j} \hat{\gamma}_{i j} \rightarrow N(0.1)
$$

We adopt three methods of estimation, FMOLS and DOLS, and the pooled mean group-ARDL by Pedroni (2001), respectively, for the robustness of the analysis. Fortunately, the DOLS while correcting for correlation between the dependent variable and the stochastic term it also adds lags of the independent variables. The FMOLS and DOLS estimators enable the calculation of asymptotic coherence by taking serial correlation into account as well as the endogeneity introduced by the presence of a cointegrating interaction. FMOLS and DOLS can be used only if the variables are integrated. Thus, this study estimates long-term elasticity using FMOLS and DOLS.

The DOLS is estimated using Eq. 2, which is given as:

$$
\begin{aligned}
& L n C 02_{i t}=\mu_{i}+x_{i, t} \Psi_{i, t}+\sum_{j=-p}^{p} \beta_{j} \operatorname{LnC02} 2_{i . t-j}+\sum_{j=-q 0}^{q 0} p_{1 . j} \operatorname{LnGDP_{i.t-j}} \\
& +p_{2 . j} \sum_{j=-q 1}^{q 1} \operatorname{LnTR}_{i . t-j}+p_{3 . j} \sum_{j=-q 2}^{q 2} \operatorname{LnE} U_{i . t-j}+\varepsilon_{i t}
\end{aligned}
$$

$p$ and $q$ are the numbers of leads/lags. The long-run relationship is estimated from the FMOLS equation given as:

$$
\begin{gathered}
\mathrm{LO}_{2}=\mu_{i}+x_{i . t} \psi+v_{i t} \\
x_{i . t}=x_{i . t}+\mathfrak{c}_{i . t}
\end{gathered}
$$

where $x 5^{*} 1$ vector of explanatory variables is, $\mu_{i}$ is the intercept, while $\mathfrak{c}_{i . t}$ and $v_{i t}$ are the error terms. However, the estimation of $\psi$ is expressed as:

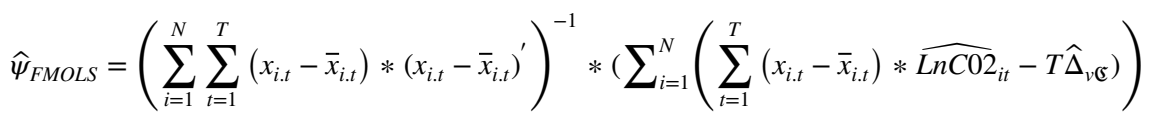

This study assesses both the short- and long-run estimates using the procedure. The examination continued with assessing the tourism GDP energy emissions nexus presented in Eq. (1) in an autoregressive distributed lag (ARDL: p, q) framework that incorporates lags of both emissions and regressors, given by: 
Table 3 Summary statistics Source: Authors computation

\begin{tabular}{lllll}
\hline & $\mathrm{LnCO}_{2}$ & LnEU & LnGDP & LnTR \\
\hline Mean & 13.59349 & 8.408557 & 10.62534 & 24.28922 \\
Median & 13.20523 & 8.294717 & 10.62813 & 24.35715 \\
Maximum & 15.57160 & 9.042578 & 10.90740 & 26.26901 \\
Minimum & 12.62240 & 7.789241 & 10.33135 & 22.31128 \\
Std. dev & 0.877578 & 0.368496 & 0.125509 & 0.843420 \\
Skewness & 1.324949 & 0.582196 & 0.042169 & 0.092158 \\
Kurtosis & 3.540713 & 1.935173 & 2.254958 & 3.078135 \\
Jarque-Bera & 51.20028 & 17.42767 & 3.935407 & 0.280544 \\
Probability & 0.000000 & 0.000164 & 0.139777 & 0.869122 \\
Sum & 2283.706 & 1412.638 & 1785.057 & 4080.589 \\
Sum sq. dev & 128.6140 & 22.67681 & 2.630674 & 118.7967 \\
Observations & 168 & 168 & 168 & 168 \\
\hline
\end{tabular}

Table 4. Cross-sectional dependency test
Dependent/ models

$\mathrm{LNCO} 2=\mathrm{f}(\mathrm{LNGDP}, \mathrm{LNTR}, \mathrm{LNEU}) \quad 2.429(0.216)$

$* * *, * *$ and $*$ are $1 \%, 5 \%$ and $10 \%$ significant level, respectively

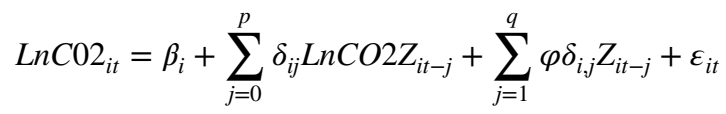

where $Z_{i t}=\left(\operatorname{LnGDP}_{i t}, \operatorname{LnTR}_{i t}, \operatorname{LnEU}_{i t}\right)$ which is a vector of explanatory variables used in this study. $\beta_{\mathrm{i}}$ represents the country-level fixed effects, $\delta_{\mathrm{ij}}$ denotes the slope of the lagged emissions variable, and $\varphi_{\mathrm{i}, \mathrm{j}}$ represents the slope of lagged explanatory variables.

The PMG-ARDL cointegration technique has become popular in empirical research because of its useful econometric benefits against the traditional panel data models. The new feature of the test concerns its ability to accommodate endogeneity issues in econometric models and at the same time treat both short-run and long-run parameters. The ARDL cointegration test is known for its adaptability regarding the appropriateness in a mixed order of integration such as I (0) or/and I (1) however unquestionably not I (2). Uncovered that the pool mean group (PMG) estimator is reliable, robust to lag orders and outliers.

\section{Results and discussion}

\subsection{Pre-estimation diagnostics}

Table 3 presents the summary statistics for the group of countries which includes the meaning, standard deviation, minimum and maximum, skewness and kurtosis values for the main variables of interest in the study. Tourist arrivals (LnTR) have the highest mean, median and maximum values. Energy use (LnEU) has the lowest value, while $\mathrm{CO}_{2}$ is the most dispersed among the variables. The correlation matrix shows that there 
Table 5 Unit root test

\begin{tabular}{|c|c|c|c|c|c|c|c|c|}
\hline \multicolumn{9}{|c|}{ Unit root test } \\
\hline \multirow[b]{3}{*}{ Variables } & \multicolumn{4}{|l|}{$\mathrm{ADF}$} & \multicolumn{4}{|l|}{$\mathrm{PP}$} \\
\hline & \multicolumn{2}{|l|}{ At level } & \multicolumn{2}{|l|}{ At $1^{\text {st }}$ Level } & \multicolumn{2}{|l|}{ At level } & \multicolumn{2}{|l|}{ At $1^{\text {st }}$ Level } \\
\hline & $\pi \tau$ & $\pi \vartheta$ & $\pi \tau$ & $\pi \vartheta$ & $\pi \tau$ & $\pi \vartheta$ & $\pi \tau$ & $\pi \vartheta$ \\
\hline $\mathrm{LnCO}_{2}$ & 0.1118 & 0.2482 & $0.0005^{* * *}$ & $0.0031 * * *$ & 0.1102 & 0.2421 & $0.0001 * * *$ & $0.0007 * * *$ \\
\hline LnGDP & 0.8606 & 0.2728 & $0.0004 *$ & 0.0021 & 0.8968 & 0.2728 & $0.0003 *$ & 0.0015 \\
\hline LnTR & 0.9613 & 0.6426 & $0.0027^{* *}$ & $0.0101 *$ & 0.9613 & 0.5775 & $0.0027 * *$ & $0.0101^{*}$ \\
\hline LnEU & 0.5736 & 0.3574 & $0.0002 * *$ & $0.0011 *$ & 0.6377 & 0.3574 & $0.0001 * *$ & $0.0009^{*}$ \\
\hline
\end{tabular}

$\pi \tau$ is with constant, $\pi \vartheta$ is with constant and trend. $* * *, * * *$, represent statistical rejection level at $0.01,0.05,0.10$ percent, respectively

Table 6 Pedroni cointegration test

\begin{tabular}{lcllll}
\hline \multicolumn{2}{l}{ Deterministic intercept and trend } & & & \\
\hline & Weighted stat & $p$ value & & Statistic & $p$ value \\
\hline Panel v-Stat & -1.969546 & $(0.9756)$ & Group rho-Stat & 0.521536 & $(0.6990)$ \\
Panel rho-Stat & $-1.290861 *$ & $(0.0984)$ & Group PP-Stat & $-8.622613 * * *$ & $(0.0000)$ \\
Panel PP-Stat & $-11.62436 * * *$ & $(0.0000)$ & Group ADF-Stat & $-6.028199 * * *$ & $(0.0000)$ \\
Panel ADF-Stat & $-9.663486 * * *$ & $(0.0000)$ & & & $(0.0000)$ \\
No deterministic trend & & & & \\
Panel PP-Stat & $-8.977449 * * *$ & $(0.0000)$ & Group ADF-Stat & $-7.441806 * * *$ \\
Panel ADF-Stat & $-8.722065 * * *$ & $(0.0000)$ & & & $(0.0506)$ \\
No deterministic intercept or trend & & & & $(0.0000)$ \\
Panel v-Stat & -0.089901 & 0.5358 & Group rho-Stat & $-1.639400 *$ & $(0.0000)$ \\
Panel rho-Stat & $-3.226552 * * *$ & $(0.0006)$ & Group PP-Stat & $-6.024529 * * *$ \\
Panel PP-Stat & $-6.388866 * * *$ & $(0.0000)$ & Group ADF-Stat & $-6.682539 * * *$ \\
Panel ADF-Stat & $-6.714354 * * *$ & $(0.0000)$ & & & \\
\hline
\end{tabular}

$* * *, * *, *$ represent statistical rejection level at $0.01,0.05$ and 0.10 percent, respectively

is a positive association between the dependent variable $\mathrm{CO}_{2}$ emissions and the independent variables in the model; GDP, tourist arrivals and energy use.

However, after accessing the correlation among the variables, it was important to prove with evidence of CD in the constructs as presented in Table 4. With the outcome, the analysis cannot proceed with analytical techniques that are robust with the CD test, but techniques that are robust with the first-generation test because both of the CD techniques use were not significant.

Consequently, we adopt the ADF Fisher and Phillips-Perron unit root tests and we find that none of the variables is stationary at level, while all of them are stationary at first difference but the various level of significance as shown in Table 5. However, in Table 6, the Pedroni cointegration test suggests that there exists a long-run cointegration relation between $\mathrm{CO}_{2}$ emissions, tourist arrivals, energy use and GDP in the G7 countries. Hence, 
Table 7 OLS, DOLS and FMOLS estimations

\begin{tabular}{llll}
\hline Variables & OLS & DOLS & FMOLS \\
\hline LnGDP & -0.319727 & 0.081096 & $0.205001 * *$ \\
$p$ value & $(0.1152)$ & $(0.5049)$ & $(0.0153)$ \\
LnTR & $0.328237 * * *$ & 0.026011 & 0.007784 \\
$p$ value & $(0.0000)$ & $(0.4035)$ & $(0.7129)$ \\
LnEU & $1.072820 * * *$ & $1.012490^{* * *}$ & $0.896588^{* * *}$ \\
$p$ value & $(0.0000)$ & $(0.0000)$ & $(0.0000)$ \\
R-SQUARE & 0.404798 & 0.999017 & 0.997785 \\
ADJ R-SQUARE & 0.397584 & 0.998060 & 0.997653 \\
\hline
\end{tabular}

***, **,* represent statistical rejection level at $0.01,0.05$ and 0.10 percent, respectively

we estimate the impact of tourist arrivals, energy use and GDP on $\mathrm{CO}_{2}$ emissions for G7 countries over the period 1995 to 2018.

\subsection{Dynamic panel data estimations}

The result of the OLS, FMOLS and DOLS regression is reported in Table 7. GDP has a positive and significant impact on emissions in the FMOLs estimate, but no significant impact is reported in the OLS and DOLS estimation. Specifically, a 1\% rise in economic growth will lead to a $0.205 \%$ rise in $\mathrm{CO}_{2}$ emissions. This result is as expected, giving that the G7 is the most industrialized group of counties in the world and constitute $46 \%$ of world GDP. Often large-scale economic activities such as manufacturing and industrial constitute $\mathrm{CO}_{2}$ emissions, and it affirms the finding of, Bekun and Gyamfi (2020) and Sarpong et al (2020).

Tourism is a driver of $\mathrm{CO}_{2}$ emissions as shown by OLS estimates, while it does not affect emissions in the DOLS and FMOLS estimations. Specifically, a $1 \%$ rise in tourist arrivals will increase emissions by $0.328 \%$. This signifies that the tourist-related activities in the G7 countries contribute to environmental degradation especially that all G7 countries are among the top tourist destinations in the world attracting more than 40 million tourists visit annually. Tourist activities such as transportation contribute immensely to $\mathrm{CO}_{2}$ emissions which depletes the quality of the environment. The finding affirms Sarpong et al (2020), Adedoyin and Bekun (2020), Gossling (2013) and Katircioglu, (2014).

Energy use is an important driver of $\mathrm{CO}_{2}$ emissions as shown by the OLS, DOLS and FMOLS. Specifically, a $1 \%$ rise in energy use will lead to about a $1 \%$ rise in $\mathrm{CO}_{2}$ emissions. The one-to-one relationship between energy use and emissions points to the huge demand for combustible energy in the G7 countries. This result also points out the fact that combustible fuel maintains a significant share of the G7 energy mix. Hence, energy use in the region makes such a huge contribution to emissions. Interestingly, energy use has the strongest explanation for emissions in the model signifying that energy use is the biggest contributor to emissions in the bloc. The outcome however confirms the finding of Adedoyin et al (2020a), Gossling and Peeters (2015) and Sbia et al. (2014).

In Table 8, we report regression results from PMG-ARDL where we show the short-run and long-run relationships. Results show that GDP makes a significant contribution to $\mathrm{CO}_{2}$ emissions in the short run and the long run. Specifically, a $1 \%$ rise in GDP will increase 


\begin{tabular}{|c|c|c|c|c|}
\hline \multicolumn{5}{|c|}{ Long-run equations } \\
\hline Variables & Coefficient & Std. error & t-statistic & $p$ value \\
\hline LnGDP & $0.495111^{* * *}$ & 0.091534 & 5.409029 & 0.0000 \\
\hline LnEU & $0.873052 * * *$ & 0.087325 & 9.997745 & 0.0001 \\
\hline LnTR & 0.005933 & 0.026150 & 0.226905 & 0.1235 \\
\hline \multicolumn{5}{|c|}{ Short-run equation } \\
\hline Variables & Coefficient & Std. error & t-statistic & \\
\hline COINTEQ 01 & $-0.328041 * * *$ & 0.113505 & -2.890110 & 0.0000 \\
\hline $\mathrm{D}\left(\mathrm{LnCO}_{2}(-1)\right)$ & -0.140161 & 0.114853 & -1.220351 & 0.2132 \\
\hline D(LnGDP) & $0.473914 * *$ & 0.186006 & 2.547844 & 0.0412 \\
\hline $\mathrm{D}(\mathrm{LnEU})$ & $0.496562 * * *$ & 0.179064 & 2.773104 & 0.0000 \\
\hline D(LnTR) & -0.032146 & 0.023973 & -1.340917 & 0.3245 \\
\hline $\mathrm{C}$ & $0.364358 * * *$ & 0.228520 & 1.594421 & 0.0000 \\
\hline
\end{tabular}

$* * *, * *, *$ represent statistical rejection level at $0.01,0.05$ and 0.10 percent, respectively

emissions by 0.496562 and $0.495 \%$ in the short run and long run, respectively. This result confirms earlier results that economic activities in the G7 countries contribute significantly to pollution and environmental degradation. This finding agrees with that of Jalil et al., (2013) for Turkey and Akpan and Akpan (2012) for Nigeria. Large-scale industrial activities in the $\mathrm{G} 7$ are responsible for a great portion of $\mathrm{CO}_{2}$ emissions in the world.

Tourism on the other hand has no effect on environmental quality in the short run or the long run implying that tourist activities do not make a significant impact on the depletion of the environment. This outcome aligns with the findings of Durbarry and Seetanah (2014) for Mauritius and Balli et al (2019) for 15 Mediterranean countries.

Consequently, energy use is found to have an important impact on rising emissions in the $\mathrm{G} 7$ countries in the short run and the long run. As shown by the results in Table 8, a 1\% increase in energy use will bring about an increase in emissions by 0.49 and $0.87 \%$ in the short run and long run, respectively. This result is in line with Saboori and Sulaiman (2013) for South-East Asian countries and Ali et al., (2017a, 2017b) for Malaysia. Even though the strength of the LNEU coefficients in this result does not appear as strong as those in the DOLS and FMOLS estimates, it still shows that the energy use in the G7 constitutes a great portion of $\mathrm{CO}_{2}$ emissions. This entails that as the $\mathrm{G} 7$ countries continue to demand energy, there will be a rise in emissions that are harmful to the natural environment.

\subsection{Causality tests}

Causality tests in Table 9 show that there is no causality between $\mathrm{LnCO}_{2}$ and LnTR and LnEU and LnGDP. There is unidirectional causality from $\mathrm{LnCO}_{2}$ to $\mathrm{LnEU}, \mathrm{LnCO}_{2}$ to LnGDP, LnTR to LnEU, LnGDP to LnTR. This result implies that tourism, energy use and economic growth have no direct effect on emissions. However, emissions predict economic growth and energy. Also, tourist arrivals predict energy use even as economic growth predicts tourism.

From the short-run analysis, it was confirmed that economic growth increases pollution within the G7 economics affirming the findings of Jalil et al., (2013) for Turkey and Akpan and Akpan (2012) for Nigeria. Energy use on the other hand also shows a positive 
Table 9 Heterogeneous causality test

\begin{tabular}{|c|c|c|}
\hline Null hypothesis: & Z-bar Stat & $p$ value \\
\hline $\mathrm{LnEU} \neq \mathrm{LnCO}_{2}$ & -0.40003 & $(0.6891)$ \\
\hline $\mathrm{LnCO}_{2} \neq \mathrm{LnEU}$ & $3.00750 * * *$ & $(0.0026)$ \\
\hline $\mathrm{LnGDP} \neq \mathrm{LnCO}_{2}$ & -0.49731 & $(0.6190)$ \\
\hline $\mathrm{LnCO}_{2} \neq \mathrm{LnGDP}$ & $1.90148 *$ & $(0.0572)$ \\
\hline $\mathrm{LnTR} \neq \mathrm{LnCO}_{2}$ & 1.23085 & $(0.2184)$ \\
\hline $\mathrm{LnCO}_{2} \neq \mathrm{LnTR}$ & -0.77288 & $(0.4396)$ \\
\hline $\mathrm{LnGDP} \neq \mathrm{LnEU}$ & 1.35953 & $(0.1740)$ \\
\hline $\mathrm{LnEU} \neq \mathrm{LnGDP}$ & 0.28260 & $(0.7775)$ \\
\hline $\mathrm{LnTR} \neq \mathrm{LnEU}$ & $1.94555 *$ & $(0.0517)$ \\
\hline LnEU $\neq$ LnTR & 0.44597 & 0.6556 \\
\hline LnTR $\neq$ LnGDP & 0.94475 & $(0.3448)$ \\
\hline $\mathrm{LnGDP} \neq \mathrm{LnTR}$ & $2.07469 * *$ & $(0.0380)$ \\
\hline
\end{tabular}

$* * *, * *, *$ represents statistical rejection level at $0.01,0.05$ and 0.10 percent, respectively, while the symbol $\neq$ denotes does Granger cause

relationship with emission indicating energy used increases pollution in the short run within the G7 economics. This result is in line with Saboori and Sulaiman (2013) for South-East Asian countries and Ali et al., (2017a, 2017b) for Malaysia. Nevertheless, tourism has shown a negative but significant connection with emissions in the short run.

The Ganger causality revealed that there is a one-way causality between these variables: $\mathrm{CO}_{2}$ emission and energy use, $\mathrm{CO}_{2}$ emission and economic growth, tourism and economic growth and economic growth and tourism.

\subsection{Discussion of findings}

This study utilized the OLS, FMOLS, DOLS as well as the pool mean-ARDL for estimation of the impact of tourism arrival, economic growth and energy use on $\mathrm{CO}_{2}$ emission for the G7 economics. From the analysis, it was observed that economic growth increases environmental degradation in the long run which affirms the finding of, Bekun and Gyamfi (2020) and Sarpong et al (2020). However, tourism is also a driver of emission in the G7 economy. This signifies that the tourist-related activities in the G7 countries contribute to environmental degradation especially that all G7 countries are among the top tourist destinations in the world attracting more than 40 million tourists visit annually. Tourist activities such as transportation contribute immensely to $\mathrm{CO}_{2}$ emissions which depletes the quality of the environment. The finding affirms Sarpong et al (2020), Adedoyin and Bekun (2020), Gossling (2013) and Katircioglu, (2014). Moreover, energy use also leads to an increase in emission in the G7 economics. This result also points out the fact that combustible fuel maintains a significant share of the G7 energy mix. Hence, energy use in the region makes such a huge contribution to emissions. Interestingly, energy use has the strongest explanation for emissions in the model, signifying that energy use is the biggest contributor to emissions in the bloc. The outcome however confirms the finding of Adedoyin et al (2020a), Gossling and Peeters (2015) and Sbia et al. (2014). This result implies that tourism, energy use and economic growth have no direct effect on emissions. However, emissions predict economic growth and energy. Also, tourist arrivals predict energy use even as economic growth predicts tourism. 


\section{Conclusion and policy implications}

This study is different from previous studies in that it jointly investigated the impact of tourist arrivals, energy use and economic growth on $\mathrm{CO}_{2}$ emissions in the $\mathrm{G} 7$ countries for the period 1995 to 2018. Using DOLS, FMOLS and PMG-ARDL estimation techniques, empirical results show that economic growth tourism and energy use are strong drivers of emissions. Moreover, the short-run analysis revealed that economic growth and energy use also increase emissions. While causality test revealed that there is unidirectional causality from $\mathrm{CO}_{2}$ to energy use, $\mathrm{CO}_{2}$ to GDP, while also tourist and GDP to tourist arrivals implying that tourism, energy use and economic growth have no direct effect on emissions, but rather emissions were found to predict economic growth and energy, while tourist arrivals predict energy use even as economic growth predicts tourism.

On the policy front, the study found that tourism contributes to emissions in the G7 countries which shows that effective promotion of environmentally friendly tourism is needed in the host countries within the G7 economics. In line with this, more emphasis should be paid to green tourism in the G7 to achieve more significant results in reducing tourism-related emissions. The governments of these nations must concentrate on diversifying economic transactions into areas that can be sustained by the countries' resources. However, fishery, manufacturing and service are examples of such operations. Tourist revenues, on the other hand, can be used to improve urban infrastructure, thus stimulating the growth and development of other economic initiatives. Nevertheless, energy use strongly drives emissions and consequently environmental degradation. Hence, the study suggests that the G7 countries implement a more aggressive energy mix policy that will comprise majorly be renewable sources of energy to reduce the harm caused on the environment as a result of the use of non-renewable energy. In the same line, it is important to check economic activities that lead to a large number of emissions through carbon tax levied on firms and countries that emit high amounts of $\mathrm{CO}_{2}$ during economic activities.

Open Access This article is licensed under a Creative Commons Attribution 4.0 International License, which permits use, sharing, adaptation, distribution and reproduction in any medium or format, as long as you give appropriate credit to the original author(s) and the source, provide a link to the Creative Commons licence, and indicate if changes were made. The images or other third party material in this article are included in the article's Creative Commons licence, unless indicated otherwise in a credit line to the material. If material is not included in the article's Creative Commons licence and your intended use is not permitted by statutory regulation or exceeds the permitted use, you will need to obtain permission directly from the copyright holder. To view a copy of this licence, visit http://creativecommons.org/licenses/by/4.0/.

\section{References}

Abdulnasser Hatemi-J., Rangan Gupta., Axel Kasongo., Thabo Mboweni., Ndivhuho Netshitenzhe (2014). "Are there asymmetric causal relationships between tourism and economic growth in a panel of G-7 Countries?" Working Papers 201476, University of Pretoria, Department of Economics.

Adedoyin, F. F., Bein, M. A., Gyamfi, B. A., \& Bekun, F. V. (2021). Does agricultural development induce environmental pollution in E7? A myth or reality. Environmental Science and Pollution Research, 1, $1-12$.

Adedoyin, F. F., \& Bekun, F. V. (2020). Modelling the interaction between tourism, energy consumption, pollutant emissions and urbanization: Renewed evidence from panel VAR. Environmental Science and Pollution Research, 27(31), 38881-38900. 
Adedoyin, F. F., Alola, A. A., \& Bekun, F. V. (2020a). An assessment of environmental sustainability corridor: The role of economic expansion and research and development in EU countries. Science of the Total Environment, 713, 136726. https://doi.org/10.1016/j.scitotenv.2020.136726

Adedoyin, F. F., Gumede, I. M., Bekun, V. F., Etokakpan, U. M., \& Balsalobre-lorente, D. (2020b). Modelling coal rent, economic growth and CO 2 emissions : Does regulatory quality matter in BRICS economies? Science of the Total Environment, 710, 136284. https://doi.org/10.1016/j.scito tenv.2019.136284

Akpan, G. E., \& Akpan, U. F. (2012). Electricity consumption, carbon emissions and economic growth in Nigeria. International Journal of Energy Economics and Policy, 2(4), 292-306.

Ali, W., Abdullah, A., \& Azam, M. (2017a). The dynamic relationship between structural change and $\mathrm{CO} 2$ emissions in Malaysia: A co-integrating approach. Environmental Science and Pollution Research, 24(14), 12723-12739.

Ali, W., Abdullah, A., \& Azam, M. (2017b). Re-visiting the environmental Kuznets curve hypothesis for Malaysia: Fresh evidence from ARDL bounds testing approach. Renewable and Sustainable Energy Reviews, 77, 990-1000.

ATAG (2019). Aviation benefits Report 2019 - Aviation: benefits beyond borders (ABBB)

Al-Mulali, U., Saboori, B., \& Ozturk, I. (2015). Investigating the environmental Kuznets curve hypothesis in Vietnam. Energy Policy, 76, 123-131.

Awan, U. (2019). Effects of buyer-supplier relationship on social performance improvement and innovation performance improvement. Int J Appl Manag Sci, 11(1), 21-35.

Awan, U., Kraslawski, A., \& Huiskonen, J. (2018). Buyer-supplier relationship on social sustainability: Moderation analysis of cultural intelligence. Cogent Bus Manag, 5(1), 1429346.

Azam, M., \& Abdullah, H. Dynamic links among tourism, energy consumption, and economic growth: Empirical evidences from top tourist destination countries in Asia. Journal of Public Affairs, e2629.

Azam, M. (2020). Energy and economic growth in developing Asian economies. Journal of the Asia Pacific Economy, 25(3), 447-471.

Azam, M., Khan, A. Q., \& Ozturk, I. (2019). The effects of energy on investment, human health, environment and economic growth: Empirical evidence from China. Environmental Science and Pollution Research, 26(11), 10816-10825.

Azam, M., Alam, M. M., \& Hafeez, M. H. (2018). Effect of tourism on environmental pollution: Further evidence from Malaysia, Singapore and Thailand. Journal of Cleaner Production, 190, 330-338.

Bagliani, M., Bravo, G., \& Dalmazzone, S. (2008). A consumption-based approach to environmental Kuznets curves using the ecological footprint indicator. Ecological Economics, 65(3), 650-661.

Balli, E., Sigeze, C., Manga, M., Birdir, S., \& Birdir, K. (2019). The relationship between tourism, CO2 emissions and economic growth: A case of Mediterranean countries. Asia Pac J Tour Res, 24(3), 219-232.

Balsalobre-Lorente, D., Driha, O. M., Bekun, F. V., \& Adedoyin, F. F. (2020). The asymmetric impact of air transport on economic growth in Spain: fresh evidence from the tourism-led growth hypothesis. Current Issues in Tourism, 24, 1-17.

Bayne, Nicholas (1998), "International economic organizations: more policymaking less autonomy", in Reinalda, Bob; Verbeek, Bertjan (eds.), Autonomous Policymaking By International Organizations (Routledge/Ecpr Studies in European Political Science, 5), Routledge, ISBN 9780415164863 , OCLC 70763323, OL 7484858M, 0415164869.

Bella, G. (2018). Estimating the tourism induced environmental Kuznets curve in France. Journal of Sustainable Tourism, 26(12), 2043-2052.

BEKUN, F. V., \& GYAMFI, B. A. (2020). Rethinking the nexus between pollutant emission, financial development, renewable energy consumption and economic growth in G7 countries. Social, Human and Administrative Sciences-II, 73.

Brilliant Maps (2015) Top 100 international tourist destination cities by country. Online available at: http://brilliantmaps.com/top-100- tourist-destinations/(Accessed on 10/02/2020)

BP Statistical Review of World Energy, (2020). https://www.bp.com/ content/dam/bp/business-sites/en/ global/corporate/pdfs/energy-economics/statistical-review/bp-stats-review-2020-full-report.pdf. Retrieved 11 may 2020

Cheam, C. L., Mahmood, R., \& Abdullah, H. (2013). Tourism, selected macroeconomics variables and economic growth: An econometrics of long run and short run relationship. International Journal of Economics and Management, 7(1), 67-83.

Coondoo, D., \& Dinda, S. (2008). Carbon dioxide emission and income: A temporal analysis of crosscountry distributional patterns. Ecological Economics, 65(2), 375-385.

Dinda, S. (2004). Environmental Kuznets curve hypothesis: A survey. Ecological Economics, 49(4), 431-455. 
Dogan, E., Tzeremes, P., \& Altinoz, B. (2020a). Revisiting the nexus among carbon emissions, energy consumption and total factor productivity in African countries: New evidence from nonparametric quantile causality approach. Heliyon, 6(3), e03566. https://doi.org/10.1016/j.heliyon.2020.e03566

Dogan, E., Ulucak, R., Kocak, E., \& Isik, C. (2020b). The use of ecological footprint in estimating the environmental Kuznets curve hypothesis for BRICST by considering cross-section dependence and heterogeneity. Science of the Total Environment, 723, 138063. https://doi.org/10.1016/j.scitotenv. 2020.138063

Durbarry, R., \& Seetanah, B. (2014). Assessing the impact of tourism and travel on climate change. Journal of Hospitality Marketing \& Management. https://doi.org/10.1080/19368623.2013.785374

Ertugrul, H. M., Cetin, M., Seker, F., \& Dogan, E. (2016). The impact of trade openness on global carbon dioxide emissions: Evidence from the top ten emitters among developing countries. Ecological Indicators, 67, 543-555. https://doi.org/10.1016/j.ecolind.2016.03.027

Etokakpan, M. U., Bekun, F. V., \& Abubakar, A. M. (2019). Examining the Tourism-Led Growth Hypothesis, Agricultural-Led Growth Hypothesis and Economic Growth in Top Agricultural Producing Economies. European Journal of Tourism Research, 21, 132-137.

Euromonitor International report (2014) Top 100 city destinations ranking - Published 2014. Online available at: http://blog.euromonitor. com/2014/01/Euromonitor-internationals-top-city-destinationsranking.html (Accessed on 10/02/2020)

Gao, J., Xu, W., \& Zhang, L. (2019). Tourism, economic growth, and tourism induced EKC hypothesis: evidence from the Mediterranean region. Empirical Economics, 60, 1-23.

Gossling, S. (2002). Global environmental consequences of tourism. Global Environmental Change, 12(4), 283-302.

Gossling, S. (2013). National emissions from tourism: An overlooked policy challenge? Energy Policy, $59,433-442$.

Gossling, S., \& Hall, C. M. (2006). Uncertainties in predicting tourist flows under scenarios of climate change. Climatic Change, 79(3/4), 163-173.

Gossling, S., \& Peeters, P. (2015). Assessing tourism's global environmental impact 1900-2050. Journal of Sustainable Tourism, 23(5), 639-659. https://doi.org/10.1080/09669582.2015.1008500

Grossman, G.M. and Krueger, A.B. (1991), "Environmental impacts of a North American free-trade agreement", No. w3914, National Bureau of Economic Research

Gyamfi, B. A., Bein, M. A., \& Bekun, F. V. (2020). Investigating the nexus between hydroelectricity energy, renewable energy, nonrenewable energy consumption on output: Evidence from E7 countries. Environmental Science and Pollution Research, 27(20), 25327-25339.

Gyamfi, B. A., Sarpong, S. Y., \& Bein, M. A. (2021a). The contribution of the anthropogenic impact of biomass utilization on ecological degradation: Revisiting the G7 economies. Environmental Science and Pollution Research, 28(9), 11016-11029.

Gyamfi, B. A., Adedoyin, F. F., Bein, M. A., Bekun, F. V., \& Agozie, D. Q. (2021b). The anthropogenic consequences of energy consumption in E7 economies: juxtaposing roles of renewable, coal, nuclear, oil and gas energy: evidence from panel quantile method. Journal of Cleaner Production, $295,126373$.

Howitt, O. J., Revol, V. G., Smith, I. J., \& Rodger, C. J. (2010). Carbon emissions from international cruise ship passengers' travel to and from New Zealand. Energy Policy, 38(5), 2552-2560.

Hughes, G. (1996). Tourism and the environment; a sustainable partnership. Scottish Geographical Magazine, 112(2), 107-113.

Hunter, C., \& Green, H. (1995). Tourism and the Environment: A Sustainable Relationship? Routledge.

Ișik, C., Ahmad, M., Pata, U. K., Ongan, S., Radulescu, M., Adedoyin, F. F., \& Ongan, A. (2020). An evaluation of the tourism-induced environmental Kuznets curve (T-EKC) hypothesis: Evidence from G7 Countries. Sustainability, 12(21), 9150.

Inglesi-Lotz, R., \& Dogan, E. (2018). The role of renewable versus non-renewable energy to the level of $\mathrm{CO} 2$ emissions a panel analysis of sub- Saharan Africa's Big 10 electricity generators. Renewable Energy, 123, 36-43. https://doi.org/10.1016/j.renene.2018.02.041

Jalil, A., Mahmood, T., \& Idrees, M. (2013). Tourism-growth nexus in Pakistan: Evidence from ARDL bounds tests. Economic Modelling, 35, 185-191.

Johansen, S., \& Juselius, K. (1990). Maximum likelihood estimation and inference on cointegration-with applications to the demand for money. Oxford Bulletin of Economics and Statistics, 52(2), 169-210.

Katircioglu, S. T. (2014). International tourism, energy consumption, and environmental pollution: The case of Turkey. Renewable and Sustainable Energy Reviews, 36, 180-187.

Katircioğlu, S. T. (2014). Testing the tourism-induced EKC hypothesis: The case of Singapore. Economic Modelling, 41, 383-391. 
Kirikkaleli, D., Adedoyin, F. F., \& Bekun, F. V. (2020). Nuclear energy consumption and economic growth in the UK : Evidence from wavelet coherence approach. Journal of Public Affairs. https:// doi.org/10.1002/pa.2130

Lee, J. W., \& Brahmasrene, T. (2013). Investigating the influence of tourism on economic growth and carbon emissions: Evidence from panel analysis of the European Union. Tourism Management, 38, 69-76.

Lin, T.P. (2010), “Carbon dioxide emissions from transport in Taiwan's national parks", Tourism Management, Vol. 31 No. 2, pp. 285-290

Liu, Y., Kumail, T., Ali, W., \& Sadiq, F. (2019). The dynamic relationship between CO2 emission, international tourism and energy consumption in Pakistan: A cointegration approach. Tour Rev, 74(4), 761-779.

Lotfalipour, M. R., Falahi, M. A., \& Ashena, M. (2010). Economic growth, CO2 emissions, and fossil fuels consumption in Iran. Energy, 35(12), 5115-5120.

Lukashina, N. S., Amirkhanov, M. M., Anisimov, V. I., \& Trunev, A. (1996). Tourism and environmental degradation in Sochi, Russia. Annals of Tourism Research, 23(3), 654-665.

Mbaiwa, J. E. (2003). The socio-economic and environmental impacts of tourism development on the Okavango Delta. North-Western Botswana. J Arid Environ, 54(2), 447-467.

Meng, M., \& Niu, D. (2011). Modeling CO2 emissions from fossil fuel combustion using the logistic equation. Energy, 36(5), 3355-3359.

Moutinho, V., Madaleno, M., Inglesi-Lotz, R., \& Dogan, E. (2018). Factors affecting CO2 emissions in top countries on renewable energies: A LMDI decomposition application. Renewable and Sustainable Energy Reviews, 90, 605-622. https://doi.org/10.1016/j.rser.2018.02.009

Nassani, A. A., Aldakhil, A. M., Abro, M. M. Q., \& Zaman, K. (2017). Environmental Kuznets curve among BRICS countries: Spot lightening finance, transport, energy and growth factors. Journal of Cleaner Production, 154, 474-487.

OECD (2014). Social expenditure update: social spending is falling in some countries, but in many others it remains at historically high levels. Insights from the OECD Social Expenditure database(SOCX), November 2014. Online available at: https://www.oecd. org/els/soc/OECD2014Social-Expenditure-Update-Nov2014- 8pages.pdf (Accessed on 12th , January, 2019)

Pao, H. T., \& Tsai, C. M. (2010). CO2 emissions, energy consumption and economic growth in BRIC countries. Energy Policy, 38(12), 7850-7860.

Peeters, P., Szimba, E., \& Duijnisveld, M. (2007). Major environmental impacts of European tourist transport. Journal of Transport Geography, 15(2), 83-93.

Pigram, J. J. (1980). Environmental implications of tourism development. Annals of Tourism Research, 7(4), 554-583.

Qureshi, M. I., Hassan, M. A., Hishan, S. S., Rasli, A. M., \& Zaman, K. (2017). Dynamic linkages between sustainable tourism, energy, health and wealth: Evidence from top 80 international tourist destination cities in 37 countries. Journal of Cleaner Production, 158, 143-155.

Rasli, A. M., Qureshi, M. I., Isah-Chikaji, A., Zaman, K., \& Ahmad, M. (2018). New toxics, race to the bottom and revised environmental Kuznets curve: The case of local and global pollutants. Renew Sust Energ Rev, 81, 3120-3130.

Saboori, B., \& Sulaiman, J. (2013). Environmental degradation, economic growth and energy consumption: Evidence of the environmental Kuznets curve in Malaysia. Energy Policy, 60, 892-905.

Saint Akadiri, S., Lasisi, T. T., Uzuner, G., \& Akadiri, A. C. (2019). Examining the impact of globalization in the environmental Kuznets curve hypothesis: The case of tourist destination states. Environmental Science and Pollution Research, 26(12), 12605-12615.

Sarpong, S. Y., Bein, M. A., Gyamfi, B. A., \& Sarkodie, S. A. (2020). The impact of tourism arrivals, tourism receipts and renewable energy consumption on quality of life: A panel study of Southern African region. Heliyon, 6(11), 05351.

Sbia, R., Shahbaz, M., \& Hamdi, H. (2014). A contribution of foreign direct investment, clean energy, trade openness, carbon emissions and economic growth to energy demand in UAE. Economic Modelling, 36, 191-197.

Scott, D., Peeters, P., \& Go“ssling, S. . (2010). Can tourism deliver its 'aspirational' greenhouse gas emission reduction targets? Journal of Sustainable Tourism, 18(3), 393-408.

Selden, T. M., \& Song, D. (1994). Environmental quality and development: Is there a Kuznets curve for air pollution emissions? Journal of Environmental Economics and Management, 27(2), 147-162.

Shaheen, K., Zaman, K., Batool, R., Khurshid, M. A., Aamir, A., Shoukry, A. M., Sharkawy, M. A., Aldeek, F., Khader, J., \& Gani, S. (2019). Dynamic linkages between tourism, energy, environment, and economic growth: Evidence from top 10 tourism-induced countries. Environmental Science and Pollution Research, 26(30), 31273-31283. 
Solarin, S. A. (2014). Tourist arrivals and macroeconomic determinants of CO2 emissions in Malaysia. Anatolia, 25(2), 228-241.

Stefanica, M., \& Butnaru, G. I. (2015). Research on tourists' perception of the relationship between tourism and environment. Procedia Economics and Finance, 20, 595-600.

Stern, D. I. (2004). The rise and fall of the environmental Kuznets curve. World Development, 32(8), 1419-1439.

Stynes DJ (1998) Economic impacts of tourism. Online available at: https://msu.edu/course/prr/840/econi mpact/pdf/ecimpvol1.pdf (Accessed on 15th January, 2019)

Tang, C. F., \& Abosedra, S. (2014). Small sample evidence on the tourism-led growth hypothesis in Lebanon. Current Issues in Tourism, 17(3), 234-246.

Trends, G. (2014). Understanding the Relationship Between Air Transportation. September

Udi, J., Bekun, F.V., Adedoyin, F.F., 2020. Modeling the nexus between coal consumption, FDI inflow and economic expansion : does industrialization matter in South Africa ? Environ. Sci. Pollut. Res.

UNWTO (2008), available at: www.e-unwto.org/doi/pdf/https://doi.org/10.18111/9789284413560

UNWTO, J. (2016). World Tourism Barometer. Vol. 14.

Verhoeven M, Gunnarsson V, Carcillo S (2007) Education and health in G7 countries: achieving better outcomes with less spending. IMF working paper series WP/07/263. Online available at: https://www.imf. org/en/Publications/WP/Issues/2016/12/31/Education-and-Health-in-G7-Countries-Achieving-BetterOutcomes-with-Less-Spending-21444. (Accessed on 15th January, 2019).

Wikiversity, (2016). Influence of Aviation On Tourism Industry. Wikiversity.

World Economic Forum (2016) Country highlights. Online available at: http://reports.weforum.org/globalcompetitiveness-report-2015-2016/country-highlights/ (Accessed on 15th December, 2018)

"World economic outlook database". International Monetary Fund. imf.org. October 2017. Major Advanced Economies (G7).

World travel and tourism council (2016). The economic impact of travel \& tourism: 2016 annual update summary, London, UK

World Tourism Organization (UNWTO). Why Tourism? http://www2.unwto.org/content/why-tourism.

Wu, T. P., Wu, H. C., Wu, S. T., \& Wu, Y. Y. (2020). Economic policy uncertainty and tourism nexus dynamics in the G7 countries: Further evidence from the wavelet analysis. Tourism Planning \& Development, 1, 1-18.

Zaman, K., Moemen, M. A. E., \& Islam, T. (2017). Dynamic linkages between tourism transportation expenditures, carbon dioxide emission, energy consumption and growth factors: Evidence from the transition economies. Current Issues in Tourism, 20(16), 1720-1735.

Zaman, K., Shahbaz, M., Loganathan, N., \& Raza, S. A. (2016). Tourism development, energy consumption and environmental Kuznets curve: Trivariate analysis in the panel of developed and developing countries. Tourism Management, 54, 275-283.

Zhang, X. P., \& Cheng, X. M. (2009). Energy consumption, carbon emissions and economic growth in China. Ecological Economics, 68(10), 2706-2712.

Publisher's Note Springer Nature remains neutral with regard to jurisdictional claims in published maps and institutional affiliations.

\section{Authors and Affiliations}

\section{Bright Akwasi Gyamfi ${ }^{1}$ Murad A. Bein ${ }^{1} \cdot$ Festus Fatai Adedoyin ${ }^{2}$ D . Festus Victor Bekun ${ }^{3,4}$}

Bright Akwasi Gyamfi

brightgyamfi1987@gmail.com

Murad A. Bein

muradabdurahmanb@gmail.com

Festus Victor Bekun

fadedoyin@bournemouth.ac.uk

1 Faculty of Economics and Administrative Sciences, Cyprus International University, Via Mersin 10, Nicosia, North Cyprus, Turkey 
2 Department of Computing and Informatics, Bournemouth University, Poole, UK

3 Faculty of Economics Administrative and Social Sciences, Istanbul Gelisim University, Istanbul, Turkey

4 Department of Accounting, Analysis and Audit, School of Economics and Management, South Ural State University, 76, Lenin Aven, 454080 Chelyabinsk, Russia 